\title{
Lexicography and Its Interdisciplinary Contacts, with Special Reference to Linguistics and Onomasiology
}

\author{
R.R.K. Hartmann, School of English, University of Exeter, Exeter, United
} Kingdom (R.R.K.Hartmann@exeter.ac.uk)

\begin{abstract}
The article attempts a first conspectus of what is known about interdisciplinary contacts between the fields of Lexicography and Linguistics, and in the process asks a range of fundamental questions on whether and how the subject matter is shared, and how we can improve mutual relations. Firstly, some opinions and arguments in the literature are reviewed, with particular attention to (a) what criteria determine the status of a discipline, (b) how various relations between Lexicography and Linguistics can be modelled, (c) how practice and theory interact, and (d) what parallels there are between the two disciplines, in terms of such notions as description, codification and remediation. Secondly, views from the position of Linguistics are categorised historically and systematically, first by tracing the development from historical-comparative or diachronic linguistics (philology) to structural-descriptive (synchronic) linguistics as well as applied linguistics, and then by combining five of the linguistic 'levels' with the three semiotic 'dimensions', and relating them to various interdisciplinary or problem-solving fields, such as sociolinguistics and computational linguistics. Thirdly, several points of view in Lexicography are presented, and an explicit framework is developed for displaying its place relative to its 'mother', 'sister' and 'daughter' disciplines as well as some of its 'data-supplying' disciplines, paying special attention to the problem of methodology. Fourthly, as a special case study, the territory of 'onomasiology' is discussed to illustrate the limitations and possibilities of various approaches to the analysis, description and lexicographic presentation of synonym and antonym sets of vocabulary. The conclusion is reached that ways must be found to understand the interdisciplinary nature of Lexicography, and a plea is made to move from mutual neglect to deliberate collaboration. (Several diagrams are used to display networks of relations; bibliographical references focus on recent work and include representative reference works for the major disciplines mentioned.)
\end{abstract}

Keywords: LEXICOGRAPHY, METALEXICOGRAPHY, THEORY AND PRACTICE, DESCRIPTION, CODIFICATION, REMEDIATION, APPLICATION, INTERDISCIPLINARY CONTACTS, LINGUISTICS, ONOMASIOLOGY, MOTHER DISCIPLINES, SISTER DISCIPLINES, DAUGHTER DISCIPLINES, DATA-SUPPLYING DISCIPLINES, METHODOLOGY, REFERENCE SCIENCE, SEMIOTICS

* This article was presented as a keynote address at the Tenth International Conference of the African Association for Lexicography, organised by the Sesiu sa Sesotho Lexicography Unit, University of the Free State, Bloemfontein, Republic of South Africa, 13-15 July 2005. 
Opsomming: Leksikografie en sy interdissiplinêre skakels, met spesiale verwysing na linguistiek en onomasiologie. Die artikel probeer ' $n$ eerste oorsig gee van wat bekend is oor interdissiplinêre skakels tussen die gebiede van die Leksikografie en die Linguistiek, en vra in die proses ' $n$ reeks grondliggende vrae oor of en hoe die vakinhoude gedeel word, en hoe ons onderlinge verwantskappe kan verbeter. Eerstens word ' $n$ aantal opvattings en argumente in die literatuur beskou, met besondere aandag aan (a) watter kriteria die status van 'n dissipline bepaal, (b) hoe verskillende verwantskappe tussen die Leksikografie en die Linguistiek gevorm kan word, (c) hoe praktyk en teorie in wisselwerking is, en (d) watter parallelle daar tussen die twee dissiplines bestaan ingevolge sulke begrippe soos beskrywing, kodifikasie en remediering. Tweedens word beskouings uit die hoek van die Linguistiek histories en sistematies gekategoriseer, eers deur die ontwikkeling na te spoor vanaf die histories-vergelykende of diachroniese linguistiek (filologie) tot die struktureel-beskrywende (sinchroniese) linguistiek sowel as die toegepaste linguistiek, en dan deur vyf van die linguistiese "vlakke" met die drie semiotiese "dimensies" saam te voeg, en hulle in verband te bring met verskillende interdissiplinêre of probleemoplossende gebiede, soos die sosiolinguistiek en die rekenaarlinguistiek. Derdens word verskeie gesigspunte in die Leksikografie aangebied, en 'n noukeurige raamwerk ontwikkel om sy plek te toon met betrekking tot sy "moeder"-, "suster"- en "dogter"-dissiplines sowel as sommige van sy "dataverskaffende" dissiplines deur spesiale aandag aan die probleem van metodologie te gee. Vierdens, as 'n spesiale gevallestudie, word die terrein van die "onomasiologie" bespreek om die beperkinge en moontlikhede van verskillende benaderings tot ontleding, beskrywing en leksikografiese aanbieding van sinoniem- en antoniem-woordeskatgroepe toe te lig. Daar word tot die gevolgtrekking gekom dat maniere gevind moet word om die interdissiplinêre aard van die leksikografie te verstaan, en 'n pleidooi word gelewer om van onderlinge verwaarlosing tot doelbewuste samewerking te beweeg. (Verskeie diagramme word gebruik om verwantskapsnetwerke te toon; bibliografiese verwysings fokus op onlangse werk en sluit verteenwoordigende naslaanwerke vir die vermelde hoofdissiplines in.)

Sleutelwoorde: LEKSIKOGRAFIE, METALEKSIKOGRAFIE, TEORIE EN PRAKTYK, BESKRYWING, KODIFIKASIE, REMEDIËRING, TOEPASSING, INTERDISSIPLINÊRE SKAKELS, LINGUISTIEK, ONOMASIOLOGIE, MOEDERDISSIPLINES, SUSTERDISSIPLINES, DOGTERDISSIPLINES, DATAVERSKAFFENDE DISSIPLINES, METODOLOGIE, VERWYSINGSWETENSKAP, SEMIOTIEK

\section{Introduction}

After many years of being involved with both lexicography and linguistics, I have an active interest in the double issue of what kinds of disciplines they are and how they relate to each other (love and hate? ivory tower and coal-face?). Other fields of potential relevance that will also be mentioned here, in passing, are lexicology, terminology, language learning, translation, and information technology.

The aims of this article are as follows: (a) to review the strengths and weaknesses of the literature (especially from the points of view of both lexicography and linguistics), (b) to examine mutual relations between them, with 
special attention to 'models' explaining these, (c) to illustrate all this with reference to the special case of onomasiology, and (d) to discuss the implications of these topics for interdisciplinary collaboration. In the process, a number of basic reference works claiming to cover the field(s) will also be highlighted.

\section{Opinions, arguments and models}

What kinds of relations can be observed between lexicography and linguistics? In an area where personal opinion still tends to overshadow solid scholarly evidence, we need to sift through the statements made from various positions. Such statements are, in any case, rather limited and selective; they depend on the theoretical framework within which respective authors work, e.g. are they concerned with the 'lexicon' as the linguistic study of vocabulary or the product of lexicographic compilation? Are they interested in the 'lexeme' as a basic unit of linguistic analysis or as one of the prototypical information carriers in the dictionary? And although the activities in question may have very long traditions, e.g. the descriptive grammar of Panini in ancient India (Lexicon Grammaticorum ed. Stammerjohann 1996: 692-697) or the even older bilingual thematic word-lists produced in ancient Mesopotamia (McArthur 1986: 24-25), the literature for both fields is relatively recent (for linguistics only five or six generations, for lexicography only two or three generations back), and publications on the interdisciplinary relations between them are still rather recent and rare indeed. But it is still worth looking for models that might help us throw light on this topic; four are presented here.

(1) The first aspect for which we need diagrammatic enlightenment is the double question of what constitutes a 'discipline', and what are the criteria for its scholarly status. One of the few authorities who have addressed these issues head-on is the German linguist and metalexicographer Wiegand who (in 1998, citing Posner) stipulated five such standards for the delineation of 'dictionary research'. Fig. 1 displays the implications of this approach for the two subject fields of linguistics and lexicography.

Fig. 1: Criteria for establishing an academic discipline

\begin{tabular}{|l|l|l|}
\cline { 2 - 3 } \multicolumn{1}{c|}{} & Linguistics & Lexicography \\
\hline subject-matter & language analysis ... & dictionary compilation ... \\
set of perspectives & variety, change ... & typology, history ... \\
research methods & informant testing .... & data-gathering ... \\
body of knowledge & linguistic units ... & lexical definition ... \\
modes of discourse & terminology ... & terminology ... \\
\hline
\end{tabular}

Lexicography, according to Wiegand, has some way to go until it can claim to be a fully developed scholarly discipline, based on a coherent subject-matter 
(e.g. compiling reference works), consistent perspectives (e.g. history and typology of reference works), replicable research methods (e.g. collecting data from informants or texts), a specific body of knowledge (e.g. information categories and how they are presented in a reference work), and convincing modes of discourse (e.g. conferences and journals). Interestingly, Lutzeier (2002: 6) has recently made similar comments about the less than universal acceptance of lexicology as a branch of linguistics, stipulating six criteria: subject matter, investigative interest, appropriate methodology, tools utilised, active participants, and public relations.

(2) A second model is required for explaining the whole range of positions from one extreme of complete dependence (Fig. 2a: lexicography considered as part of linguistics, but not usually linguistics as part of lexicography) through relative interdependence (Fig. 2b: mutual relations) between the two subjects to relative independence (Fig. 2c) of each of them.

Fig. 2a: Inclusion

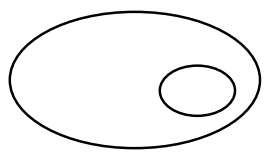

Fig. 2b: Mutuality



Fig. 2c: Independence

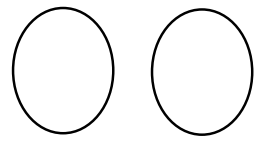

The first view (Fig. 2a) is suggested by a minority of linguists who have defined lexicography as "a branch of applied linguistics" (Svensén 1993: 1) or even as "a branch of applied lexicology" (Dictionary of Language and Linguistics comps. Hartmann and Stork 1972: 129 and also A First Dictionary of Linguistics and Phonetics comp. Crystal 1980: 210). The second (Fig. 2b) is held by those who are in favour of healthy interdependence, e.g. "lexicography and linguistics are now inextricably mixed" (Béjoint 1994: 177) for the reason that "precision and quality of work" in the former often has to rely on evidence provided by the latter (Alvar Ezquerra 1995: 193-194 and 2003: 366). The third position (Fig. 2c) is taken either by those lexicographers who are suspicious of academic linguists (Landau 1984/2001) or by theoretical and applied linguists who manage to ignore lexicography (and lexicology) altogether (Encyclopedic Dictionary of Applied Linguistics eds. Johnson and Johnson 1998).

(3) To complicate matters further, both lexicography and linguistics exhibit two sides or aspects of their field, 'practice' and 'theory'. How can this fact be modelled? Linguistics and lexicography indeed have a lot in common in terms of practical activities and theoretical perspectives, but traditionally the former has always had a more academic image, while the latter, as we have already noted, has sometimes been called (merely) an 'art and craft' or an 'applied field'. While there are now many more textbooks, monographs, journals, and conference proceedings available for lexicography, the number of dictionary research cen- 
tres is still very small, and there are even fewer university professorships (most of them in neighbouring subjects such as linguistics and modern languages). Fig. 3 depicts the potential relations between practice and theory in both disciplines.

Fig. 3: Linguistic/lexicographic practice and metalinguistic/metalexicographic theory



Practical activities include such multi-stage operations as (a) observation or data-gathering (in linguistics said to include both 'fieldwork' and 'intuition', in lexicography 'recording' and 'corpus collection'), (b) description (called 'analysis' in linguistics and 'editing' in lexicography), and (c) presentation (called 'system of rules' in linguistics and 'publishing' in lexicography). The theoretical concerns lead to such perspectives as (i) criticism (prescription/dictionary criticism), (ii) classification (linguistic variety/dictionary typology), (iii) history (language change/dictionary history), (iv) structure (linguistic levels/information categories), (v) use (linguistic usage/dictionary use) and (vi) automation (computational linguistics/dictionary IT).

The path from practice to theory is usually one of model-building and generalisation (metalinguistics/metalexicography), while the opposite route, from theory to practice, may be termed 'feedback' and assumed by implication to lead to improvements in the linguistic/lexicographic process(es). This direction is sometimes called 'application', but the term can also have several other connotations (see below).

(4) There are certainly parallels between linguistics and lexicography, then, as indicated in the diagrams above, but are there suitable models for their systematic interaction? One attempt I made myself many years ago (Hartmann 1979: 2) was to suggest that there seems to be a gradual progression from (linguistic) theory and description to codification, even remediation and practical problemsolving. Another contribution to the topic of linguistics vis-à-vis other disciplines concerned with codification (such as orthography, grammar and lexicography) was written by Haugen from the point of view of language planning. In a paper first published in 1980 and reprinted as part of a collection, Haugen (1987: 60) stated that "to some degree linguistics owes its existence to the practical services linguists could offer as codifiers of language", and that "the typi- 
cal product of codification has been a prescriptive orthography, grammar, and dictionary".

Fig. 4: From (linguistic) description to (lexicographic) codification (and remediation)

\begin{tabular}{|l|l|l|l|}
\hline theory & description & codification & remediation/problem-solving \\
\hline discourse & textology & textography & style; rhetoric \\
sentence(s) & grammar & grammatography & composition; language learning \\
vocabulary & lexicology & lexicography & definition; translation \\
letter(s) & graphology & orthography & writing; spelling \\
sound(s) & phonology & orthoepy & pronunciation; speech therapy \\
\hline
\end{tabular}

From left to right, the columns in Fig. 4 indicate these three kinds of utilisation of linguistic expertise: 'description' (observation of individual and collective linguistic usage), 'codification' (production of prescriptive works, e.g. usage guides, grammars, and dictionaries) and 'remediation' (application of linguistic knowledge to problem-solving areas such as speech therapy, spelling, and translation). From bottom to top these are arranged in order of structural levels, from small/simple to large/complex units of linguistic communication (and also roughly in the historical order in which they have become established).

This tabulation is not complete, however. Thus, the line starting with 'vocabulary' could be supplemented, for instance, by (technical) terminology, terminography and standardisation; more needs to be said, too, about the role of vocabulary in language learning and teaching. Some of the special fields mentioned in Fig. 4 have become labels for professional disciplines represented in and promoted by national and international societies. Thus, in a recent submission to a Higher Education exercise (May 2004), the British Association for Applied Linguistics (BAAL) has stressed that (a) "Applied Linguistics cannot truly be considered as a branch of Linguistics", (b) "the two disciplines often have markedly different research practices", and (c) the field of applied linguistics embraces quite a range of 'subject areas' from child language to sign language, including lexicography and lexicology (Carter 2004: 2-4). Similarly, within the International Association of Applied Linguistics (AILA) and its triennial congresses, some 25 'scientific commissions' have been active for a number of years, including Lexicography and Lexicology, Language Planning, Rhetoric and Stylistics, Interpreting and Translation, Contrastive Linguistics and Error Analysis, Literacy, and Second Language Acquisition.

Most of these disciplines, and some of the mutual contacts and interactions between them, are covered in two book series, first Current Trends in Linguistics (14 volumes published by Mouton in the 1960s and 1970s) and then the comprehensive Handbücher zur Sprach- und Kommunikationswissenschaft (HSK), some in multi-volume sets, issued by Walter de Gruyter since the early 1980s. 25 HSK volumes have been published, and 11 more are in preparation, on such 
fields as semiotics (4 volumes), (the history of) linguistics, morphology, syntax, semantics, lexicology (2 volumes), lexicography (3 volumes), onomastics ( 2 volumes), languages for special purposes (2 volumes), sociolinguistics (2 volumes), psycholinguistics, computational linguistics, media studies, and translation (some of these will be referred to below).

Two other handbook series covering some of these disciplines, but on a much more limited scale, are available from Oxford University Press and Blackwell Publishing. In one of the Blackwell volumes, The Handbook of Applied Linguistics (eds. Davies and Elder 2003), the useful distinction is made between 'linguistics applied' (L-A) and 'applied linguistics' (A-L), the former being concerned with real-world language data for understanding language and evaluating linguistic theory (e.g. in language description, lexicography, corpus linguistics and stylistics), while the latter covers problem-based approaches for understanding language use and remedying social problems (e.g. in language learning, language for special purposes, language testing and language planning).

Most of these subjects are comprehensively covered in the Kenkyusha Dictionary of Applied Linguistics (ed. Koike 2003). It is worth noting, from the perspective of this article, that the 2nd edition of the Encyclopedia of Language and Linguistics (first published 1994), currently in preparation, is intended to have a much broader and deeper coverage of the field of Lexicography. For more on the linguistic standpoint, see Section 3 below; for that of lexicography, see Section 4; for the special case of onomasiological lexicography, see Section 5.

\section{The view from Linguistics}

What kind of discipline is linguistics? As has been noted above, it can tend either more towards theoretical model-building or practical problem-solving, but both of these are grounded in a long tradition, as so-called 'diachronic linguistics' and 'synchronic linguistics'. The history of the subject is well documented in Arens (1955/1969) in terms of (a) prescientific endeavours associated with Ancient Greece and Rome and the Medieval and Modern periods, (b) 19th-century philological scholarship and (c) various phases and schools of 20th-century structural, descriptive and cognitive linguistics. One of the most important influences on the development of lexicography was exerted by comparative-historical linguists who, according to Collison (1982), stimulated much of the work on so-called historical dictionaries for many of the Indo-European languages, such as the Deutsches Wörterbuch by the Grimm brothers and the Oxford English Dictionary by James Murray et al.

There has always been interaction with other academic disciplines, of course, e.g. biology (especially during the 19th century), philosophy (during the early 20th century), and more recently the so-called 'hyphenated disciplines' of sociolinguistics (The Handbook of Sociolinguistics ed. Coulmas 1998), psycholinguistics (Psycholinguistik/Psycholinguistics. An International Handbook 
eds. Deutsch et al. 2003), ethno- and anthropological linguistics, and 'lexicomputing' in the form of corpus linguistics and computational linguistics (Dodd 1989, Ooi 1998, and the Oxford Handbook of Computational Linguistics eds. Mitkov et al. 2003).

Over the years, the hierarchical relationships between various linguistic levels and units, as specified in Fig. 4 above, have been further developed into component branches of the discipline: from sounds to phonetics and phonology (and orthoepy), from writing to graphetics and graphology (and orthography), from words to morphology and lexicology (and lexicography), from sentences to grammar (and grammatography), from discourse to textology (and stylistics and rhetoric), from language variety to dialectology, from language affiliation to linguistic typology, etc. Throughout this time, some linguists have also shown a regular concern for making themselves useful by 'applying' their knowledge to fields like language planning, language teaching and translation, which in turn has given rise to new specialisations, e.g. contrastive linguistics and languages for special purposes (LSP).

In Fig. 5 (based on a diagram in Hartmann 1991: 2855), five of the levels of linguistic structure are combined with the three dimensions distinguished in semiotics, resulting in 15 divisions of descriptive (and contrastive) linguistics that can then be used in the codification of usage information in monolingual or bilingual dictionaries. Conversely, information presented in dictionaries can be used by linguists for verifying usage data.

Fig. 5: Levels of linguistic analysis

\begin{tabular}{|l|l|l|}
\hline paradigmatic dimension & syntagmatic dimension & pragmatic dimension \\
\hline text semantics & text syntax & text pragmatics \\
morphology & syntax & pragma-grammar \\
lexical semantics & semotactics & pragma-lexicology \\
segmental graphology & graphotactics & pragma-graphology \\
segmental phonology & phonotactics & pragma-phonology \\
\hline
\end{tabular}

For example, at the level of lexicology it may be possible to distinguish the different meanings of a polysemous word in terms of its membership of a particular lexical field, collocation or context, although there is no guarantee that the resulting linguistic explanation is automatically the best way for presenting its senses in the dictionary. Neither can we be sure that words considered by linguists as having similar meanings within the language (intralingual synonyms) or as being translatable into another language (interlingual equivalents) are necessarily the ideal candidates for lexicographic treatment in a thesaurus. Thus, within the field labelled 'contrastive lexicology' by Wikberg (1983), the vocabulary handled in the practical bilingual dictionary may not correspond either to the 'theoretical lexicon' as defined in linguistics or the 'mental lexicon' as studied in psycholinguistics. On the other hand, Martin (2003) has suggested 
that lexicology and lexicography could be brought together by systematically linking the translation equivalents found in bilingual dictionaries for several language pairs.

Linguists can therefore be shown to be both 'donors' to and 'users' of the work of lexicographers. Thus, it is possible not only to note whether and in what way(s) dictionary compilers depend on previous linguistic studies, e.g. for deciding what kinds of semantic information to present in the dictionary (Hartmann 1972, Svensén 1993), but also to verify how linguists in turn utilise lexicographic information for checking the evidence of the meaning range (e.g. in definitions and contextual examples) or the etymological background (e.g. origin and semantic change) of certain vocabulary items (Harras 1989, Hanks 2003).

\section{The view from Lexicography}

What kind of field is lexicography? In its practical manifestation of compilation or dictionary-making, it has a very long tradition which has already been documented in a number of monographs: McArthur (1986) has pursued the universal anthropological background, Boisson et al. (1991) have investigated the early beginnings of both the Western and Eastern traditions of monolingual and bilingual lexicography, Starnes and Noyes (1946/1991) have traced the story of English dictionary-making from Cawdrey to Johnson, and Van Hoof (1995) has shown that the compilation of bilingual dictionaries is often tied to the practice of translation. The currently best textbook on the compilation process is by Landau (1984/2001), who in its revised and updated 2nd edition covers most aspects of planning, managing and editing dictionaries, including the changes brought about by computer technology. The most ambitious attempt so far to survey the whole field is the three-volume encyclopedia Wörterbücher / Dictionaries/Dictionnaires (eds. Hausmann et al. 1989-1991).

Lexicography as theory, on the other hand, is a very recent phenomenon. In one of the most critical overviews of the status of metalexicography, Wiegand (1998) has sketched out several of its perspectives or branches, most notably the study of dictionary use. In a three-volume reader (Hartmann 2003), I have myself used these headings for grouping the 70 texts reprinted there into nine parts: compiler perspectives, critical perspectives, user perspectives, historical perspectives, regional perspectives, linguistic perspectives, typological perspectives, structural perspectives, and interdisciplinary perspectives. In one of the contributions to the final (ninth) part based on the chapter on methodology in another recent book, I proposed a model to show how lexicography is related to a number of other disciplines. In Fig. 6 below, which is based on that diagram (Hartmann 2001: 123), these are variously referred to as 'mother', 'sister' and 'daughter' disciplines as well as 'data-supplying' disciplines. 
Fig. 6: Interdisciplinary contacts of lexicography

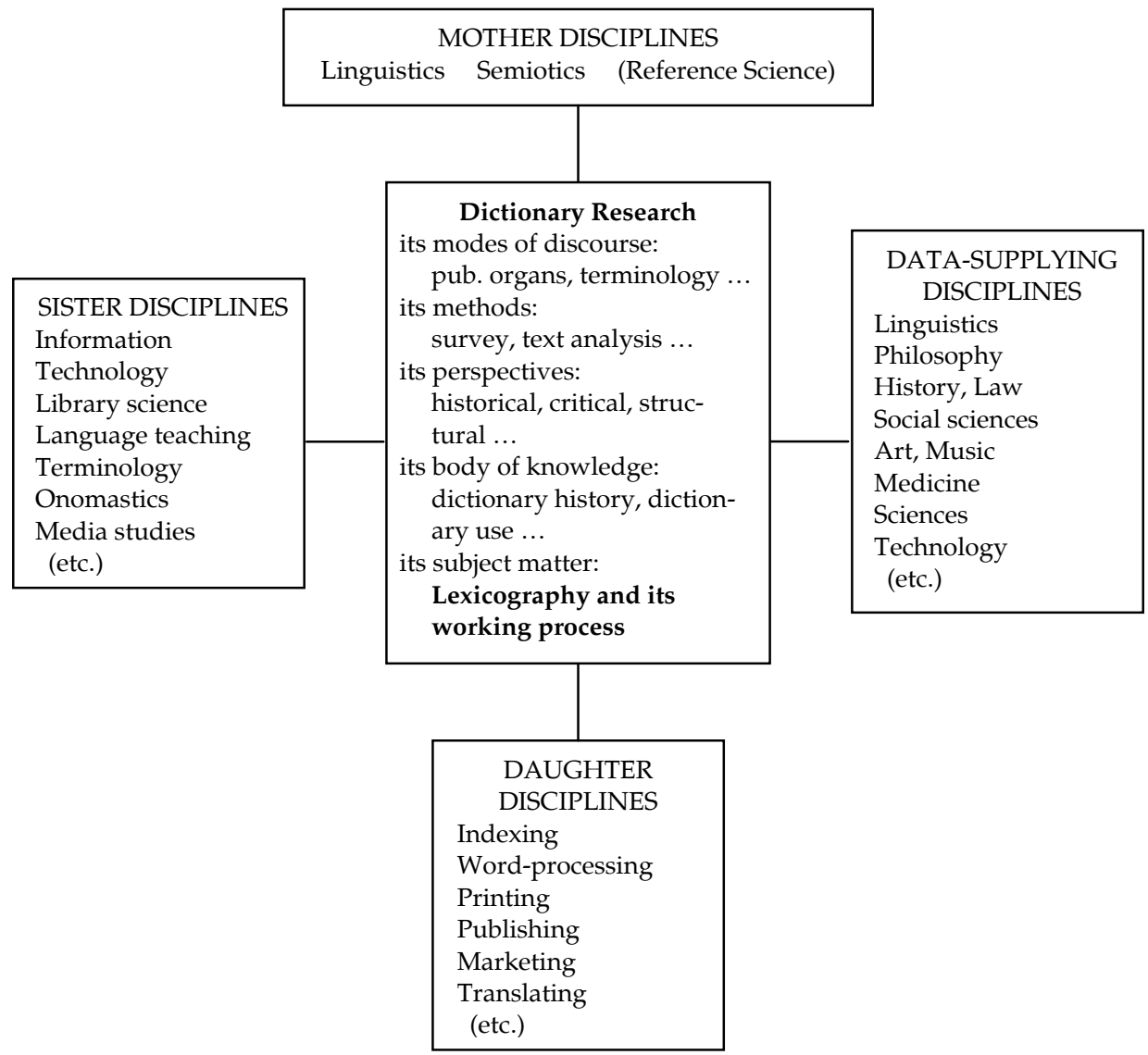

Lexicography, both as practical compilation process and as theoretical dictionary research, is displayed in the central box, taking account, in reverse order, of Wiegand's five criteria for disciplinarity as indicated in Fig. 1 (Section 2) above.

The mother disciplines comprise at least three:

(1) Linguistics, since Meier (1969) argued, well before the rise of applied linguistics as a fashionable new field, that the sceptical love-hate relationship between linguists and lexicographers should be replaced by a more sensible attitude of constructive give and take, e.g. in terms of such issues as determining the word-list in the historical dictionary, discriminating senses within entries, and sifting and treating specific etymological, grammatical and lexical information. More recently, some of us have made the case for more bridge-building in these respects (Hartmann 1996, Hartmann 2001/2003); 
(2) Semiotics, since Rey-Debove (1971) showed that lexicographers have to work within a wider frame-work of language, communication and information. Some more progress has been achieved along these lines in the intervening years (see the handbook Semiotik/Semiotics eds. Posner et al. 1998-2004);

(3) 'Reference science', since McArthur (1998: 218) saw it as an overarching, but not yet fully established specialisation and defined it as "all aspects of organizing data, information, and knowledge in any format whatever, for any purpose whatever, using any materials whatever".

At least seven sister disciplines are relevant:

(1) Information technology, a powerful force that has extended the frontiers of lexicography as well as many linguistic topic areas, involving all systems and tools for the collection, processing and presenting of reference data (Wilks et al. 1996);

(2) Library science, especially those aspects of it that concern the provision of 'reference services' (Katz 1998);

(3) Language teaching and related problem-solving areas, which are explored in the Longman Dictionary of Language Teaching and Applied Linguistics (comps. Richards et al. 1992) and the Routledge Encyclopedia of Language Teaching and Learning (ed. Byram 2000), although their entries on lexicographic notions tend to be rather superficial, ignoring recent work on the user perspective;

(4) Terminology, in relation (and sometimes in opposition) to technical or special-purpose lexicography, is treated in the Handbook of Terminology Management (eds. Wright and Budin 1997/2001) and the international handbook Fachsprachen/Languages for Special Purposes (eds. Hoffmann et al. 1998/1999);

(5) Onomastics, the study of personal and place names, remains an often neglected specialisation, well surveyed in Name Studies. An International Handbook of Onomastics (eds. Eichler et al. 1995);

(6) Media studies, a collective term for the field which investigates newspapers, radio, television and film, often together with the technologies on which they are based (The Complete A-Z Media and Communication Studies Handbook comp. Price 1997);

(7) Translation, the field concerned with the theory of interlingual mediation and the training of translators (The Routledge Encyclopedia of Translation Studies ed. Baker 2001). 
Whether the contact is with 'mother' or 'sister' disciplines, given sufficiently frequent and intensive collaboration, new bridge subjects may develop. At the intersection between language teaching and lexicography, for instance, we have seen the emergence of 'pedagogical lexicography'; at the point of contact with information technology, the new field of 'computational lexicography' (or dictionary IT) has become established, which in turn interacts with linguistics under such banners as computational lexicology and corpus linguistics. Other areas of potential interdisciplinary linkage already referred to include sociolinguistics, psycholinguistics, translation studies, LSP/terminology and language testing, each of them sometimes occurring in combination with applied linguistics and/or information technology.

To illustrate the potential links with psycholinguistics, the English linguist Crystal (1986) has argued that in our search for better dictionaries, we need more observational evidence on what constitutes better dictionary makers as well as better dictionary users. In relation to LSP and terminology, Kretzenbacher (2002) has demanded more attention to interdisciplinary and intercultural dimensions in the study of technical vocabulary, particularly in respect of the issue of whether lexical relations within and between scientific disciplines are 'open or 'closed'. And at the borderline between pedagogical and computational lexicography, Campoy Cubillo and Safont Jordà (2004) have explored the exciting potential of electronic dictionaries in foreign-language learning.

At the bottom of Fig. 6 appear those daughter disciplines which provide a service function for the various organisational and technological processes that lexicographers are charged to perform, such as typography, text manipulation (including pictorial illustrations) and - especially for bilingual dictionaries translation. Finally, on the right of the page there is an incomplete and potentially infinite list of data-supplying disciplines which are basic for dictionary projects, especially those devoted to the production of technical (encyclopedic or terminological) lexica. Some of these, like law and medicine, have very long traditions, others are more recent, such as linguistics (for usage dictionaries and dictionaries of linguistics), history (for dictionaries of historical events and personalities), even lexicography itself (for dictionaries of lexicography, e.g. the Dictionary of Lexicography ed. by Hartmann and James 1998/2001).

A good example of how these various mother, sister, daughter and datasupplying disciplines interact is the dissertation on bilingual technical lexicography by Wang (2001): it lies at the crossroads of lexicography, LSP and contrastive linguistics and shows how German-English dictionaries of electrical engineering are classified, structured and used, providing empirical details previously unavailable. What this study - and some of the ones cited in the previous paragraphs - demonstrate is the need for more information on how lexicography can be improved, not least by appealing to corpus evidence. This process is, of course, even more complex if aimed at the production of bilingual reference works, which would require parallel text corpora in addition to an understanding of the interdisciplinary links with translation. A case study of 
this topic is provided by Kwong et al. (2004) who show how the sister disciplines of terminology and IT can be brought to bear on the extraction of technical terms from two languages (English and Chinese), the data-supplying discipline being law. However, it could be argued (Hartmann 2004) that the results might be even more reliable if the text corpus was not based on the sentenceby-sentence alignment of parallel texts which are translated court judgements, but on the expert comparison of terms found in independently formulated discourse which is similar both in content and context.

We must also take note of the less obvious fact, already hinted at in Sections 2 and 3 above, that interdisciplinary links are often mutual. Just as the lexicographer typically processes data based on the subject matter of other disciplines, the practitioners of these disciplines regularly use dictionaries as information sources, whether as scholars while checking facts or as trainees while learning basic concepts. For an example of various forms of collaboration not only in the direction from linguistics (as 'applied theory') to lexicography, but also from lexicography (as 'common sense' practice) to linguistics and other 'basic' and 'neighbouring' (or mother and sister) disciplines, see Herbst et al. (2004), one of several volumes in 'Lexicographica Series Maior' devoted to interdisciplinary bridge-building.

\section{The special case of Onomasiology}

What kind of field is onomasiology? It lies right between lexicography and linguistics, since it is concerned with the problem of 'meaning' and its treatment in the dictionary, both in terms of intralingual sense relations between vocabulary items within a language and of interlingual equivalence relations between vocabulary items in two or more languages. This is usually put in the form of the bipolar distinction between 'semasiology' (or sign interpretation) and 'onomasiology' (or name allocation). The traditional general monolingual dictionary is semasiological in the sense that it provides an explanation of the meaning(s) of a given word by means of definitions or examples (from word to meaning - for helping native speakers 'decode' or comprehend). More specialised onomasiological dictionaries such as thesauruses, on the other hand, start with a given concept or meaning and provide a range of lexical choices for expressing that notion (from meaning to word - for assisting with 'encoding' or composition).

It is not surprising, then, that the linguistic disciplines of semantics and lexicology as well as the whole of lexicography have claimed this important territory, in order to understand, model and improve the presentation of sense relations, for the benefit of native speakers and foreign learners. Various theories and models have been proposed to describe such lexical properties (componential analysis, semantic fields, frame semantics and prototype semantics), and various reference works have tried to codify their essential features (nom- 
enclators, promptoria, usage guides and vocabulary builders), none with fully satisfactory completeness. One recurring example is the domain of 'seats' (chair, bench, couch, sofa etc.), which has been investigated, decomposed and tabulated by structural, anthropological and cognitive linguists (like Gipper, Pottier, Fillmore, Wierzbicka and Burkhanov), and referred to by the (meta-)lexicographer Van Sterkenburg (1992: 524) as an "evergreen from structuralism". But long before all this tentative modelling in linguistic semantics, lexicographers from Girard to Roget had to cope with the notion of overlapping meanings in their synonym dictionaries and thesauruses. The history of Roget's Thesaurus and some of his predecessors, contemporaries and successors is documented in Hüllen (2004), but a comparative study of such dictionaries in various languages is still outstanding.

A number of observations can be made on the development and nature of such onomasiological reference works. Most are monolingual, but for the more popular languages bilingual synonym dictionaries exist, too; there is even a polyglot comparative Dictionary of Selected Synonyms in the Principal Indo-European Languages (Buck 1949), which deals with the word field of 'seats' in terms of one entry, chair (within the notion 'Dwelling, House, Furniture', between bed and table), listing its equivalents in Greek, Latin, French, English, German and 20 other languages, but the comment on those selected says that "not included are words which may denote any kind of 'seat'...".

For English, a recent survey (Hartmann forthcoming) elicited 158 titles for the 20th century alone. Most of these are alphabetic, but a minority in the thesaurus tradition are arranged thematically into taxonomic clusters, e.g. 'couches and sofas' would be treated within the class 'the home' and the sub-class 'furniture'. Some early synonym dictionaries attempted to discriminate individual members of conceptually related groups of words (they are therefore called 'distinctive'), but more recent products, partly under the influence of Roget's Thesaurus, tend to merely enumerate them in ('cumulative') list form, thus making it almost impossible to know exactly what distinguishes, say, a couch from a sofa. Sometimes the boundary between a semasiological dictionary and an onomasiological thesaurus is deliberately blurred, e.g. in the French tradition by the so-called 'analogical' dictionary or in the English tradition by the increasingly popular 'dictionary and thesaurus' hybrid, especially since it has become relatively easy to combine the two genres electronically (Calzolari 1988).

During the last few years, there has been a convergence of such disciplines as (case) grammar and (frame) semantics, both within 'cognitive' linguistics and in relation to lexicography (and metalexicography), all supported by IT. This trend is documented in at least three recent thematic issues of the International Journal of Lexicography 3(4), 13(4), 16(3) and 17(2). Thus, summarising developments since WordNet, a psycholinguistically inspired lexicon of semantic associations which specifies synonyms, hypernyms, hyponyms, holonyms, meronyms and other coordinate terms for most of the more frequent vocabu- 
lary items, Fontenelle (2000: 231) introduces four papers "on the representation of collocational, thesauric and semantic knowledge and on the extraction of such knowledge from [electronic] language resources". More recently, Atkins et al. (2003: 356-357), assessing the potential uses of FrameNet, another American approach to computer-aided semantic analysis, conclude that "(t)he potential value of this resource for lexicographic practitioners is surely greater than that of any currently available way of accessing corpus data". And in the current issue of the International Journal of Lexicography, four (Dutch) models of multilingual databases are discussed in their relevance to the compilation of bilingual dictionaries, e.g. Janssen (2004) on the potential uses of 'concept lattices' as illustrated in Fig. 7.

Fig. 7: A synonym network

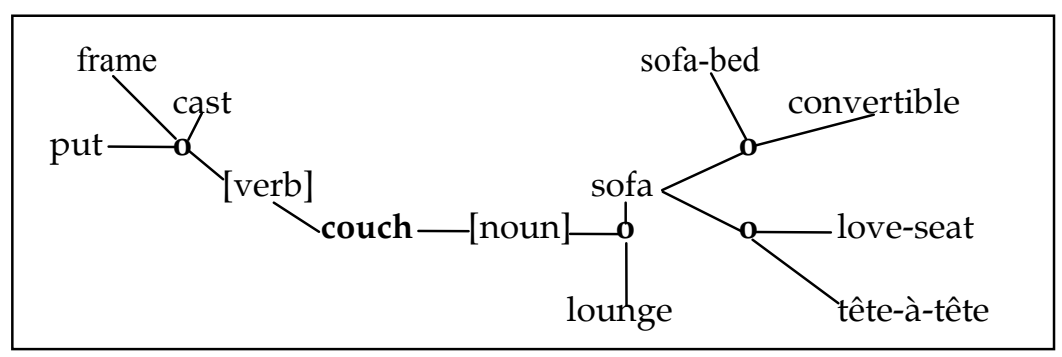

The synonym cluster associated with the word couch is shown here in the kind of semantic constellation diagram that can be found in the displays of the Visual Thesaurus ${ }^{\dagger}$, first as verb with the meaning 'to formulate', leading on to at least three possible synonyms (put, frame and cast) and then as a noun with several distinct meanings, one of which ('upholstered seat for more than one person') leads on to the synonyms lounge and sofa, and from the latter further to 'upholstered seat for more than one that can be changed into a bed' with two synonyms (sofa-bed and convertible) and to 'small sofa for two' with two more (love-seat and tête-à-tête).

This is one of several modes of presentation that are becoming available in the early 21st century, although it is difficult to keep track of the emerging formats and genres. The volume edited by Campoy Cubillo and Safont Jordà (2004) makes a contribution to the terminological classification, qualitative evaluation and pedagogical integration of these digital reference media. Thus, Tono (2004) distinguishes five types of electronic interfaces (CD-ROM, Hyperlink, Pop-up mode, Parallel format, and Pocket e-dictionary); other contributions survey the advantages and limitations of specific digital and Web-based products. The new generation of $\mathrm{CD}$ dictionaries, for example the 'Smart' Thesaurus associated with the Cambridge Advanced Learner's Dictionary and the 'Genie' Thesaurus linked to the Oxford Advanced Learner's Dictionary and the Oxford Collocations Dictionary for Students of English, can be used for word searches, text searches 
and sound searches in both decoding and encoding contexts, e.g. during wordprocessing activities. Thus, for the word couch a range of synonyms and other related words will appear in the former, from armchair and chaise longue to lounge and sofa, together with definitions and examples. In the latter, collocational information is also included, as well as links to illustrations and study pages.

For users with appropriate IT skills, these reference experiences are promising indeed. However, instruction and persistence is often required to exploit them fully on a practical level, and ideally the 'new' material needs to be tested against both user practices for their effectiveness and corpus evidence for their reliability. To verify exactly what denotational and connotational differences there are between words like couch and sofa, for example, would in turn require more interdisciplinary contacts with such fields as semantics, sociolinguistics and computational linguistics.

\section{Conclusion}

A number of links between lexicography and linguistics have been explored and quite a few issues have been raised in this article, e.g. what does 'applied' mean in terms of disciplinary status, methodology, problem-solving and improving practice? Many of these are yet to be addressed, but already we have seen some possibilities of theoretical and practical advances, with special attention to onomasiological lexicography and information technology.

A number of desiderata have emerged. The emphasis has been on English and the European context, but a global and comparative view is also needed (cf. Huang 1994); we further need to re-evaluate older methodologies and explore new ones, e.g. corpus technology; several neglected areas must be developed, e.g. linguistic versus encyclopedic knowledge, general versus technical vocabulary; lexicographic training and dictionary instruction must be improved; most of all, we need to move from mutual ignorance and distrust to more intensive interdisciplinary collaboration.

All this will have important implications in the future for academic institutions, dictionary publishers and dictionary users.

\section{Endnote}

$+\quad$ www.visualthesaurus.com, published by Plumb Design (1998-2004) as an electronic adaptation of WordNet, developed at Princeton University by Miller et al. (1990). In the Visual Thesaurus, the basic meanings indicated graphically by small circles are correlated with definitions which appear in boxes when pointed at by the mouse; they can also be called up and compared with related ones in a marginal column on the right side of the screen. 


\section{Bibliography}

\section{Dictionaries and other reference works}

Cambridge Advanced Learner's Dictionary ed. by Patrick Gillard. 2003. Cambridge: Cambridge University Press [with CD-ROM 'Smart' Thesaurus].

(The) Complete A-Z Media and Communication Studies Handbook comp. by Stuart Price. 1997. London: Hodder Arnold.

Deutsches Wörterbuch comp./ed. by Jacob Grimm and Wilhelm Grimm (et al.). 1852-1960. (16 volumes) Berlin/Göttingen: Hirzel.

Dictionary of Language and Linguistics comp. by R.R.K. Hartmann and F. Colin Stork. 1972. Barking: Applied Science Publishers.

Dictionary of Lexicography comp. by R.R.K. Hartmann and Gregory James. 1998/2001. London: Routledge.

(A) Dictionary of Selected Synonyms in the Principal Indo-European Languages comp. by Carl D. Buck. 1949. Chicago: University Press.

Encyclopedia of Language and Linguistics ed. by R.E. Asher. 1994. (10 volumes) Oxford: Pergamon. [2nd edn by E. Keith Brown in preparation; 14 volumes projected by Elsevier.]

Encyclopedic Dictionary of Applied Linguistics ed. by Keith Johnson and Helen Johnson. 1998. Oxford: Blackwell.

Fachsprachen/Languages for Special Purposes. An International Handbook of Special Language and Terminology Research ed. by Lothar Hoffmann et al. 1998, 1999. HSK Vols. 14.1, 14.2. Berlin: W. de Gruyter.

(A) First Dictionary of Linguistics and Phonetics comp. by David Crystal. 1980. The Language Library. London: A. Deutsch.

(The) Handbook of Applied Linguistics ed. by Alan Davies and Catherine Elder. 2003. Oxford: Blackwell Publishing.

(The) Handbook of Sociolinguistics ed. by Florian Coulmas. 1998. Oxford: Blackwell Publishing.

Handbook of Terminology Management ed. by Sue Ellen Wright and Gerhard Budin. 1997, 2001. (2 volumes) Amsterdam: J. Benjamins.

Kenkyusha Dictionary of Applied Linguistics/Oyogengogaku Jiten ed. by Ikuo Koike. 2003. Tokyo: Kenkyusha.

Lexicon Grammaticorum. Who's Who in the History of World Linguistics ed. by Harro Stammerjohann. 1996. Tübingen: M. Niemeyer.

Lexikologie/Lexicology. An International Handbook on the Nature and Structure of Words and Vocabularies ed. by D. Alan Cruse et al. 2002. HSK Vol. 21.1. Berlin: W. de Gruyter.

Longman Dictionary of Language Teaching and Applied Linguistics 2nd edn comp. by Jack C. Richards et al. 1992. Harlow: Longman.

Name Studies. An International Handbook of Onomastics ed. by Ernst Eichler et al. 1995/1996. HSK Vols. 11.1, 11.2. Berlin: W. de Gruyter.

Oxford Advanced Learner's Dictionary of Current English 6th edn by Sally Wehmeier. 2000. Oxford: Oxford University Press [with CD-ROM 'Genie' Thesaurus]

(The) Oxford English Dictionary comp./ed. by James A.H. Murray (et al.). 1884-1928. (1st edn 10 volumes) 1933. (Supplement); comp./ed. by Robert Burchfield. 1972-1986. (4-volume Supplement); comp./ed. by John Simpson and Edmund Weiner. 1989. (2nd edn 20 volumes) Oxford: Clarendon Press.

(The) Oxford Handbook of Computational Linguistics ed. by Ruslan Mitkov. 2003. Oxford: Oxford University Press. 
Oxford Collocations Dictionary for Students of English ed. by Margaret Deuter et al. 2003. Oxford: Oxford University Press [with CD-ROM 'Phrasebuilder'].

Psycholinguistik/Psycholinguistics. An International Handbook ed. by Werner Deutsch et al. 2003. HSK Vol. 24. Berlin: W. de Gruyter.

Routledge Encyclopedia of Language Teaching and Learning ed. by Michael Byram. 2000. London: Routledge.

(The) Routledge Encyclopedia of Translation Studies ed. by Mona Baker. 1998. London: Routledge.

Semiotik/Semiotics. A Handbook on the Sign-Theoretic Foundations of Nature and Culture ed. by Roland Posner et al. 1997, 1998, 2003, 2004. HSK Vols. 13.1, 13.2, 13.3, 13.4. Berlin: W. de Gruyter.

Thesaurus of English Words and Phrases comp. by Peter Mark Roget. 1852 (and many later editions). London: Longman.

Wörterbücher. Ein internationales Handbuch zur Lexikographie/Dictionaries. An International Encyclopedia of Lexicography/Dictionnaires. Encyclopédie internationale de lexicographie ed. by Franz J. Hausmann et al. 1989, 1990, 1991. HSK Vols. 5.1, 5.2, 5.3. Berlin: W. de Gruyter.

\section{Other literature}

Alvar Ezquerra, Manuel. 1995. Los diccionarios del español en su historia. International Journal of Lexicography 8(3): 173-201. [Reprinted as 'Dictionaries of Spanish in their historical context' in Hartmann, R.R.K. (Ed.). 2003. Lexicography. Critical Concepts. Vol. II: 343-374.]

Arens, Hans. 1955/1969. Sprachwissenschaft. Der Gang ihrer Entwicklung von der Antike bis zur Gegenwart. Orbis Academicus. Freiburg: K. Alber.

Atkins, Sue et al. 2003. The Contribution of FrameNet to Practical Lexicography. International Journal of Lexicography 16(3): 333-357.

Béjoint, Henri. 1994/2000. Tradition and Innovation in Modern English Dictionaries. [2nd edn published as Modern Lexicography. An Introduction.] Oxford: Clarendon Press.

Boisson, Claude et al. 1991. Aux origines de la lexicographie: les premiers dictionnaires monolingues et bilingues. International Journal of Lexicography 4(4): 261-315.

Calzolari, Nicoletta. 1988. The Dictionary and the Thesaurus Can Be Combined. Evens, Martha Walton (Ed.). 1988. Relational Models of the Lexicon. Representing Knowledge in Semantic Networks. Studies in Natural Language Processing. Cambridge: Cambridge University Press.

Campoy Cubillo, María Carmen and M. Pilar Safont Jordà (Eds.). 2004. Computer-mediated Lexicography in the Foreign Language Learning Context. Collecció Estudis Filològics 18. Castelló de la Plana: Publicacions de la Universitat Jaume I.

Carter, Ronald. 2004. Report from the Chair. BAAL News 77: 2-4.

Collison, Robert L. 1982. A History of Foreign-Language Dictionaries. The Language Library. London: A. Deutsch/Oxford: Blackwell. [Chapter 11, 'The Contribution of Historical and Comparative Linguistics', reprinted in Hartmann, R.R.K. (Ed.). 2003. Lexicography. Critical Concepts. Vol. II: 52-64.]

Crystal, David. 1986. The Ideal Dictionary, Lexicographer and User. Ilson, Robert (Ed.). 1986. Lexicography: An Emerging International Profession: 72-81. The Fulbright Papers Vol. I. Manchester: Manchester University Press. [Reprinted in Hartmann R.R.K. (Ed.). 2003. Lexicography. Critical Concepts. Vol. III: 319-327.]

Dodd, W. Steven. 1989. Lexicomputing and the Dictionary of the Future. James, Gregory (Ed.). Lexicographers and Their Works: 83-93. Exeter Linguistic Studies 14. Exeter: University of Exeter Press. [Reprinted in Hartmann R.R.K. (Ed.). 2003. Lexicography. Critical Concepts. Vol. III: 351-362.] 
Fontenelle, Thierry. 2000. Introduction: Dictionaries, Thesauri and Lexical-semantic Relations. International Journal of Lexicography 13(4): 229-231 [followed by 4 papers on the theme of the issue].

Fontenelle, Thierry. 2003. Introduction. International Journal of Lexicography 16(3): 231 [followed by 5 papers et al. on the theme of the issue].

Hanks, Patrick. 2003. Lexicography [Chapter 3]. Mitkov, Ruslan (Ed.). 2003. The Oxford Handbook of Computational Linguistics: 48-69.

Harras, Gisela. 1989. Wörterbücher als Hilfsmittel der linguistischen Forschung. Hausmann, F.J. et al. (Ed.). 1989. Wörterbücher/Dictionaries / Dictionnaires. Vol. I: 159-163.

Hartmann, Reinhard R.K. 1972. Über den Einfluß der linguistischen Semantik auf die englischamerikanische Lexikographie. Linguistik und Didaktik 3: 197-208.

Hartmann, Reinhard R.K. (Ed.). 1979. Dictionaries and Their Users. Papers from the 1978 BAAL Seminar on Lexicography. Exeter Linguistic Studies. Exeter: University of Exeter Press.

Hartmann, Reinhard R.K. 1991. Contrastive Linguistics and Bilingual Lexicography. Hausmann, F.J. et al. (Ed.). 1991. Wörterbücher/Dictionaries / Dictionnaires. Vol. III: 2854-2859.

Hartmann, Reinhard R.K. 1994. The Onomasiological Dictionary in English and German. A Contrastive Textological Perspective. Hüllen, W. 1994: 137-149.

Hartmann, Reinhard R.K. 1996. Lexicography as an Applied Linguistic Discipline. Hartmann, R.R.K (Ed.). Solving Language Problems: 230-244. Exeter Linguistic Studies. Exeter: University of Exeter Press.

Hartmann, Reinhard R.K. 2001. Teaching and Researching Lexicography. Applied Linguistics in Action Series. Harlow: Pearson Education. [Chapter 8, 'Methods in dictionary research', reprinted in Hartmann, R.R.K. (Ed.). 2003. Lexicography. Critical Concepts. Vol. III: 429-444.]

Hartmann, Reinhard R.K. (Ed.). 2003. Lexicography. Critical Concepts. London: Routledge.

Hartmann, Reinhard R.K. 2004. Lexicography and Translation. Chan, Sin-Wai (Ed.). Translation and Bilingual Dictionaries: 7-21. Lexicographica Series Maior 119. Tübingen: M. Niemeyer.

Hartmann, Reinhard R.K. Forthcoming. Onomasiological Dictionaries in 20th-century Europe. Lexicographica. International Annual for Lexicography.

Haugen, Einar. 1987. Blessing of Babel. Bilingualism and Language Planning. Problems and Pleasures. Berlin: W. de Gruyter.

Herbst, Thomas et al. (Eds.). 2004. Lexikografie, ihre Basis- und Nachbarwissenschaften. (Englische) Wörterbücher zwischen 'common sense' und angewandter Theorie. Lexicographica Series Maior 118. Tübingen: M. Niemeyer.

Huang, Jianhua. 1994. Chinese and Western Metalexicography. Flowerdew, L. and A.K.K. Tong (Eds.). Entering Text: 228-238. Hong Kong: HKUST Language Centre. [Reprinted in Hartmann, R.R.K. (Ed.). 2003. Lexicography. Critical Concepts. Vol. III: 391-404.]

Hüllen, Werner (Ed.). 1994. The World in a List of Words. Lexicographica Series Maior 58. Tübingen: M. Niemeyer.

Hüllen, Werner. 1999. English Dictionaries 800-1700. The Topical Tradition. Oxford: Oxford University Press.

Hüllen, Werner. 2004. A History of Roget's Thesaurus. Oxford: Oxford University Press.

Janssen, Maarten. 2004. Multilingual Lexical Databases, Lexical Gaps, and SIMuLLDA. International Journal of Lexicography 17(2): 137-154.

Katz, Bill. 1998. Cuneiform to Computer. A History of Reference Sources. History of the Book Series 4. Lanham MD: The Scarecrow Press. [Chapter 2, 'Reference Books from Cuneiform to Computer', reprinted in Hartmann, R.R.K. (Ed.). 2003. Lexicography. Critical Concepts. Vol. III: 405421.] 
Kretzenbacher, Heinz L. 2002. Wissenschaftsbezogene Wortschätze [Article 114]. Cruse, D.A. et al. (Ed.). 2002. Lexikologie/Lexicology: 919-925.

Kwong, Oi Yee et al. 2004. Alignment and Extraction of Bilingual Legal Terminology from Context Profiles. Terminology 10(2): 81-99.

Landau, Sidney. 1984/2001. Dictionaries. The Art and Craft of Lexicography. New York: C. Scribner/Cambridge: Cambridge University Press.

Lutzeier, Peter R. 2002. Der Status der Lexikologie als linguistische Disziplin [Article 1]. Cruse, D.A. et al. (Ed.). 2002. Lexikologie/Lexicology: 1-14.

Martin, Willy J.R. 2003. Lexicography, Lexicology, Linking and the Hub-and-spoke Model. Botha, Willem (Ed.). 'n Man wat beur. Huldigingsbundel vir Dirk van Schalkwyk: 268-285. Stellenbosch: Buro van die WAT.

McArthur, Tom. 1986. Worlds of Reference. Lexicography, Learning and Language from the Clay Tablets to the Computer. Cambridge: Cambridge University Press.

McArthur, Tom. 1998. What Then Is Reference Science?' [Chapter 17]. Tom McArthur. 1998. Living Words. Language, Lexicography, and the Knowledge Revolution: 215-222. Exeter: University of Exeter Press. [Reprinted in Hartmann, R.R.K. (Ed.). 2003. Lexicography. Critical Concepts. Vol. III: 422-428.]

Meier, Hans H. 1969. Lexicography as Applied Linguistics. English Studies 50: 141-151. [Reprinted in Hartmann, R.R.K. (Ed.). 2003. Lexicography. Critical Concepts. Vol. III: 307-318.]

Miller, George A. et al. 1990. Introduction to WordNet: An On-line Lexical Database. International Journal of Lexicography 3(4): 235-244.

Ooi, Vincent B.Y. 1998. Computer Corpus Lexicography. Edinburgh Textbooks in Empirical Linguistics. Edinburgh: Edinburgh University Press.

Rey-Debove, Josette. 1971. Étude linguistique et sémiotique des dictionnaires français contemporains. Approaches to Semiotics 13. The Hague: Mouton.

Starnes, DeWitt T. and Gertrude E. Noyes. 1946/1991. The English Dictionary from Cawdrey to Johnson 1604-1755. Chapel Hill NC: University of North Carolina Press. [2nd edn by Gabriele Stein. Amsterdam: J. Benjamins. Chapter 17, 'Thomas Dyche and William Pardon's A New General English Dictionary (1735)', reprinted in Hartmann, R.R.K. (Ed.). 2003. Lexicography. Critical Concepts. Vol. II: 15-28.]

Svensén, Bo. 1993. Practical Lexicography. Principles and Methods of Dictionary-Making. Oxford: Oxford University Press.

Tono, Yukio. 2004. Research on the Use of Electronic Dictionaries for Language Learning: Methodological Considerations. Campoy Cubillo, M.C. and M.P. Safont Jordà (Eds.). 2004: 13-28.

Van Hoof, Henri. 1995. Translators and the Writing of Dictionaries. Delisle, Jean and Judith Woodsworth (Eds.). Translators through History: 229-242. Benjamins Translation Library 13. Amsterdam: J. Benjamins.

Van Sterkenburg, Piet G.J. 1992. Electronic Onomasiology: Van Dale Greater Dictionary of Synonyms. Tommola, Hannu et al. (Ed.). EURALEX '92 Proceedings: 519-526. Studia Translatologica A.2. Tampere: Tampereen Yliopisto.

Wang, Weiwei. 2001. Zweisprachige Fachlexikographie. Benutzunsforschung, Typologie und mikrostrukturelle Konzeption. Angewandte Sprachwissenschaft 8. Frankfurt: P. Lang.

Wiegand, Herbert E. 1998. Wörterbuchforschung. Untersuchungen zur Wörterbuchbenutzung, zur Theorie, Geschichte, Kritik und Automatisierung der Lexikographie. Berlin: W. de Gruyter.

Wikberg, Kay. 1983. Methods in Contrastive Lexicology. Applied Linguistics 4(3): 213-221.

Wilks, Yorick A. et al. 1996. Electric Words: Dictionaries, Computers and Meanings. Cambridge MA: MIT Press. 